\title{
Using multi-hub structures for international R\&D : Organizational inertia and the challenges of implementation
}

Citation for published version (APA):

Criscuolo, P., \& Narula, R. (2005). Using multi-hub structures for international R\&D : Organizational inertia and the challenges of implementation. MERIT, Maastricht Economic Research Institute on Innovation and Technology. MERIT-Infonomics Research Memorandum Series No. 025 https://doi.org/10.26481/umamer.2005025

Document status and date:

Published: 01/01/2005

DOI:

10.26481/umamer.2005025

Document Version:

Publisher's PDF, also known as Version of record

Please check the document version of this publication:

- A submitted manuscript is the version of the article upon submission and before peer-review. There can be important differences between the submitted version and the official published version of record.

People interested in the research are advised to contact the author for the final version of the publication, or visit the DOI to the publisher's website.

- The final author version and the galley proof are versions of the publication after peer review.

- The final published version features the final layout of the paper including the volume, issue and page numbers.

Link to publication

\footnotetext{
General rights rights.

- You may freely distribute the URL identifying the publication in the public portal. please follow below link for the End User Agreement:

www.umlib.nl/taverne-license

Take down policy

If you believe that this document breaches copyright please contact us at:

repository@maastrichtuniversity.nl

providing details and we will investigate your claim.
}

Copyright and moral rights for the publications made accessible in the public portal are retained by the authors and/or other copyright owners and it is a condition of accessing publications that users recognise and abide by the legal requirements associated with these

- Users may download and print one copy of any publication from the public portal for the purpose of private study or research.

- You may not further distribute the material or use it for any profit-making activity or commercial gain

If the publication is distributed under the terms of Article $25 \mathrm{fa}$ of the Dutch Copyright Act, indicated by the "Taverne" license above, 


\section{MERIT-Infonomics Research Memorandum series}

Using multi-hub structures for international R\&D: Organizational inertia and the challenges of implementation

\section{Paola Criscuolo \& Rajneesh Narula}

\section{5-025}

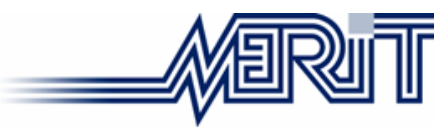

MERIT - Maastricht Economic Research Institute on Innovation and Technology

PO Box 616

6200 MD Maastricht

The Netherlands

$\mathrm{T}:+31433883875$

F: +31 433884905

http://www.merit.unimaas.nl e-mail:secr-merit@merit.unimaas.nl

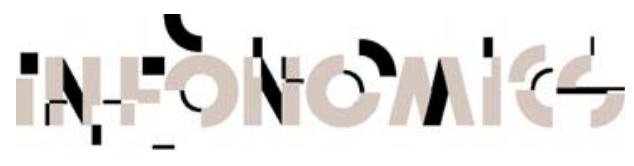

International Institute of Infonomics

c/o Maastricht University

PO Box 616

6200 MD Maastricht

The Netherlands

$\mathrm{T}:+31433883875$

F: +31 453884905

http://www.infonomics.nl

e-mail: secr@infonomics.nl 


\title{
Using multi-hub structures for international R\&D: organizational inertia and the challenges of implementation
}

\author{
Paola Criscuolo \\ (Innovation Studies Centre, Tanaka Business School, Imperial College)
}

and

Rajneesh Narula*

(University of Reading and the Copenhagen Business School)

We gratefully acknowledge comments by Bjorn Ambos.

* Corresponding author: University of Reading Business School, PO Box 218, Whiteknights, Reading, RG66AA. E-mail: r.narula@reading.ac.uk 


\section{Using multi-hub structures for international R\&D: organizational inertia and the challenges of implementation}

Abstract: Over the last decade or so, multinational enterprises (MNEs) have shifted from centralised hub structures to multi-hub structures. While these new structures provide greater potential for cross-fertilization of technologies and access to locationspecific competences, promoting effective knowledge transfer within an MNE especially in their R\&D activities - presents significant managerial challenges. Using evidence collected on the R\&D activities of MNEs in the pharmaceutical sector, this paper analyses the challenges associated with complexities of promoting and integrating knowledge flows in the face of inter-unit geographical, organizational and technological distance. MNEs are faced with organizational inertia that hinders efficient lateral communication and inter-unit knowledge transfer, and the evidence suggests that while socialization mechanisms help overcoming some of these bottlenecks, there remain a number of obstacles in optimising knowledge flows in physically and technologically dispersed R\&D facilities.

\section{INTRODUCTION}

In a relatively short span of three decades, the extent, spread, motivation, location and nature of the overseas $R \& D$ activities of multinational firms (MNEs) has become incredibly complex. Some of these changes reflect the increasingly complex nature of MNE activities, as the nature of headquarters - subsidiary relationships have been reorganised away from an ethnocentric, home country dominated structure, to a more widely distributed and complex network of knowledge flows between subsidiaries and headquarters in several locations. As recently as the 1970s, technology transfer was predominantly uni-directional from headquarters to overseas subsidiaries, and R\&D primarily asset-exploiting in nature, incremental and associated with demand-driven 
innovative activities. The situation today is one where R\&D activities are located overseas increasingly to augment and acquire new assets. MNEs undertake more strategic innovation abroad, with the intention of acquiring and internalising technological spillovers that are host location-specific. Thus there is increasing specialization of R\&D activities between subsidiaries in different locations to take advantage of specialized immobile knowledge assets. This is reflected in the growing geographical spread of MNE's centres of excellence (see for example Holm and Pedersen 2000), the growing phenomenon of reverse technology transfer (e.g. Håkanson and Nobel 2000, Håkanson and Nobel 2001, Zhou and Frost 2003), and the adoption of new $R \& D$ organizational structures where foreign subsidiaries contribute as much as the home location of the MNE to the creation of new technological assets (e.g. Chiesa 1996a, Gassmann and von Zedtwitz 1999, von Zedtwitz and Gassmann 2002). MNEs are moving away from a 'centralised hub’ to a multi-hub 'integrated network'.

However, it is one thing to implement a dispersed R\&D structure; it is quite another to achieve successful and efficient coordination, since personnel and management do not always adapt to these new structures, as they require inordinate amounts of coordination as well as new knowledge-exchange and networking abilities. There are a number of barriers to the internal knowledge diffusion process connected to interunits geographical, organizational and technological distance and also to the motivational disposition of both the sender and the receiver units (see Gupta and Govindarajan 2000, Kogut and Zander 1993, Szulanski 1996). Thus if firms want to reap the benefits of a geographically dispersed $R \& D$ organization, they must ensure that knowledge generated in different units of the network is transferred to the rest of the organisation and this requires the adoption of new mechanisms for the 
dissemination and integration of both explicit and tacit knowledge. In other words, firms experiences a certain amount of organizational inertia, in that despite new structure being implemented, knowledge flows and coordination de facto continue to sub-optimally follow the same patterns associated with the old structure.

This paper aims to analyse what are the managerial challenges in achieving knowledge transfer inside multi-hub integrated $R \& D$ network organizations and in overcoming organizational inertia. In particular this study assesses what are the organizational and socialization mechanisms in the R\&D organization in the internal knowledge diffusion and integration process. Knowledge resides in individuals and knowledge flows within the firm take place in social communities, i.e. in networks of relationships among organizational members. The literature on social capital (e.g. Hansen 1999, Tsai and Ghoshal 1998) has highlighted the importance of the creation of social structures in the diffusion of knowledge within and across organizational units. Research has shown that the use of socialisation mechanisms is positively related to knowledge flows within the MNE (Gupta and Govindarajan 2000). Particularly in the $\mathrm{R} \& \mathrm{D}$ context the adoption of socialisation mechanisms can facilitate the transfer of knowledge, especially in the tacit form, through the creation and maintenance of personal relationships.

The paper is organized as follows. Section 2 discusses the theoretical framework focusing on the concept of organizational inertia and on the internal barriers to interunit knowledge flows. Section 3 outlines the methodology of the study. Section 4 describes the main distribution of the innovation activities and $R \& D$ organisation across geographically dispersed units. Section 5 reports the empirical findings of the study on mechanisms employed to ensure that technical knowledge crosses both 
geographical and disciplinary boundaries, and on the role of socialization mechanisms in this process. The final section concludes the paper.

\section{ORGANISATIONAL INERTIA AND THE CHALLENGES OF THE MULTI-HUB STRUCTURE}

Traditionally the most strategic and 'core' innovation activities were concentrated in the central R\&D unit in the home country of the MNE. In this model, dubbed the ‘centralised hub’ (Bartlett 1986), there was only one centre and MNEs relied largely on one location, i.e. the home country, as the principal source of their competitive advantage. In this organisational setting the flow of knowledge was mainly in one direction: from the headquarters, where it was created, to the subsidiaries, where it was further developed to adapt products and processes to the local market (see Figure 1). However during the mid-1980s a different organisational model was proposed to take account of the fact that MNEs were facing increasing pressures towards 'global integration and responsiveness to local conditions' (Bartlett 1986). In this context MNEs could not rely only on exploiting internationally the technological assets built on home-country competences, but had to source knowledge from each leading market and national technology system. As a result the so-called 'integrated network' (Bartlett 1986) organisational model was proposed. In the integrated R\&D network structure each R\&D unit assumes a leading role in the creation of unique competences that can be leveraged by the rest of the organisation (see Figure 2). Within this model, the creation of new technologies is not the prerogative of the centre, but rather takes place in foreign subsidiaries building on and exploiting host countries' competitive advantage.

With the shift from centralised to multi-hub structures communication among different R\&D units is even more crucial as complex sets of formal and informal 
institutions need to be redesigned and developed. In the integrated network model technological upgrading emerges from complex external and internal knowledge flows both between subsidiaries and from the centre to the periphery. Thus the firm has to move away from the management of a set of dyadic relationships between the centre and the foreign R\&D unit and adopt a more systemic coordination mechanism in order to promote intensive communication flows, both within networks internal to the firm, and between external and internal networks.

\section{ORGANIZATIONAL INERTIA}

However firms show a 'persistent organizational resistance to architectural change' (Hannan et al. (2002), i.e. they suffer from organisational inertia. Inertia implies a lethargy to change, and that a state of affairs continues to be so, unless an exogenous force is applied to change it. Inertia implies that firms will prefer to maintain the status quo, until a change in circumstances requires the firm to do so. Firms are by definition loathe to radical change, and firms will always prefer to maintain the status quo if it does not endanger their competitiveness.

As Hannan and Freeman (1984) explain, structures evolve in response to the organisational need to maintain a certain amount of reliability and accountability, and in order to achieve these objectives, institutionalisation of routines and standardisation of processes is required. However, these characteristics that provide stability also result in inertia. The level of inertia is increased when there is a high level of complexity, which makes it even more difficult to reorganise. Organisations marked by a high degree of complexity and opacity tend to show higher levels of inertia (Hannan et al. 2002). 
While organisational structures are relatively easy to change - often by fiat by headquarters - implementing these changes systemically through an organisation often requires fundamental changes in the institutions that make organisational structures efficient, and it is here that organisational inertia faces its greatest challenges. Major changes that derive from changing the raison d'être of an organisation require new institutions, which -especially informal ones -evolve only gradually over time. In the case of $R \& D$ activities the most significant issues are the 'know-who'. Suppliers, professors, private research teams and informal networks of like-minded researchers take considerable effort to create, and once developed, have a low marginal cost of maintaining. Such informal institutions, are however, specific to particular research areas and specialisations, and are difficult to transfer from one organisation to another, and have often taken years to develop. This creates two types of problems. First, researchers are not prone to share this knowledge with other research teams in other locations, even where they are part of the same MNE. Second, it is difficult to shift R\&D personnel from one area of specialisation or location to another without experiencing a drop in efficiency or employee attrition.

Firms are path-dependent, and find it costly to break away from existing technological routines towards radically new or different concepts. There are additional costs involved in switching trajectories which may impede organisational change and exacerbate the level of uncertainty and therefore economic risk. Organizational structures (and particularly informal and formal institutions between $R \& D$ personnel) tend to have evolved to address particular kinds of challenges, and the flexibility that less complex and less specialised units (say, sales, production, marketing) may be able to show are simply not always present in R\&D organisations. 
Organizational inertia is in itself neither a 'good' or a 'bad' thing. Where stability, predictability, replicability and reliability are important, inertia can have positive effects, when rapidity of response is required to uncertainty and complex milieu's, inertia may impede change. $R \& D$ organizations require a mix of these two circumstances, and this requires considerable investment in coordinating and achieving knowledge diffusion and integration.

\section{BARRIERS TO INTER-UNIT KNOWLEDGE FLOWS}

It is often argued that transfer of knowledge within units belonging to the same organisation is easier to achieve than is the transfer of knowledge between organisations (Grant 1996, Kogut and Zander 1992) and that the main competitive advantage of multinationals lies in the possibility of transferring and integrating knowledge generated by subsidiaries located in different countries. However, several authors have pointed out that knowledge transfer even within organisations is far from being an automatic process.

Internal knowledge diffusion can be impaired by inter-unit technological distance within the MNE who have shifted to a differentiated R\&D network. Knowledge sharing requires that the sender and receiver have a common set of prior knowledge. The increased level of technological specialisation and diversification in the R\&D organisational network may reduce the amount of shared knowledge hindering the process of knowledge transfer. In other words, technological specialisation may introduce inter-unit differences in 'absorptive capacity' (Cohen and Levinthal 1990 p. 128). As demonstrated by Szulanski (1996) and Gupta and Govindarajan (2000), absorptive capacity in the receiving unit is a necessary condition for the successful transfer of knowledge. If the increasing level of internal technological specialisation can be an obstacle to the diffusion of knowledge it may also represent the main 
strength of the integrated $R \& D$ network structure. Enhancement of the quality of the innovation process may derive from the international cross-fertilisation of knowledge within individual technologies and/or the recombination of knowledge across related technologies (Zander 1999).

Also, international $R \& D$ configurations tend to reflect facilities that have been acquired through $M \& A$, long-standing $R \& D$ facilities and newly-established ones. In other words, there is considerable organisational distance that derives from nontechnological differences. Many of these individual establishments have had little or no history of cooperating, and indeed in may instances have been engaged in interunit rivalry under a centralised hub model, or in the case of newly acquired operations, have been de jure competitors. Achieving a harmony of inter-facility division of labour is all the more difficult because of these inter-unit rivalries. This increases the role of headquarters in coordinating and improving lateral communications.

Both organizational and technological distance problems are further exacerbated by the fact that in $R \& D$, different aspects require different organisational structures, rather than a 'one-size-fits-all' approach. In the case of basic research, personnel tend to have very little interaction with the day-to-day operations of the firm. Interactions tend to be governed by informal institutions, and organisational structure is loose and flexible in order to cope with the complexity. Units tend to be small and very highly specialised in very strongly delineated niches, and may even be said to be 'overspecialised'. Encouraging cross-fertilization requires overcoming much stronger barriers than in any other aspect of value adding activity. At the other extreme, development work requires considerable interaction with production and marketing activities within the firm, as well as customers. There are often numerous formal 
institutions and routines that have been established, and organisational structure much 'tighter'. Development activities can be more easily concentrated in a few locations, often close to the primary markets, and can service a variety of different technologies and markets.

Geographical distance also plays an important role. The tacit and firm-specific nature of technology means that knowledge spillovers that are the fundamental to achieve cross-fertilisation are more efficiently internalised when in close physical proximity between the units, or between the individual researchers. Early studies by Allen (1970, 1977) showed that physical proximity affects the likelihood of communication among $R \& D$ staff within technical functions and between technical functions and other functions in a firm. Although these problems have been mitigated by developments in ICT, which have facilitated the management and coordination of international research networks, geographical distance is still a barrier to the transfer of knowledge especially if it is tacit in nature (Howells 1995). Distant R\&D units find it difficult to communicate because the exchange of their knowledge takes place mainly through personal contacts (De Meyer 1993).

These challenges of geographical distances naturally also reflect different national cultures of units as well as organisational cultures. The adoption of a geographically distributed R\&D organization implies the existence of a strong cultural heterogeneity which creates barriers to knowledge sharing. The lack of a common culture and greater autonomy may introduce motivational barriers in the subsidiary to transfer technology within the organisation. As Cyert (1995) points out, there is the possibility that affiliates might be reluctant to transfer knowledge to other units of the MNE because they lose an 'information monopoly' within the company and their status as a 'centre of competence' in a specific area. The motivational element can be particular 
important in determining knowledge transfer from units that have been recently acquired, although with time this effect can fade way.

\section{Promoting INTER-UNIT KNOWLEDGE FLOWS}

One of the means to achieve knowledge transfer and integration is the creation of a common culture and convergence towards the same set of values, what Gupta and Govindarajan (2000) define as socialization mechanisms, i.e. job rotations among subsidiaries and between subsidiaries and headquarters. Hedlund (1986) recognized the importance of human resource management in the 'heterarchical' model: “In order for internalisation of norms to take place, a lot of rotation of personnel and international travel and postings are necessary...Advances in information technology may help the formation of the nervous system of the firm, but this will not be enough for building internal cultures” (p. 29, emphasis added).

Particularly in the R\&D context the adoption of socialization mechanisms are crucial in facilitating technology transfer because they help to establish inter-personal relationships through which less codified form of knowledge can be shared. Crossborders research projects, temporary international assignments to other R\&D units, site rotations of researchers, short-term visits, exchange programs are some of the practices used to promote the formation of social ties among R\&D personnel working in distant laboratories (Bartlett and Ghoshal 1990, Chiesa and Manzini 1996, De Meyer 1993, Persaud et al. 2001, Teigland et al. 2000, Westney 1993, Zhou and Frost 2003). What is most important is that personal relationships tend to last also once the scientists stop working together or they return back to their original R\&D facility (Agrawal et al. 2003). As argued by Zhou and Frost (2003) international project teams create a common understanding and help to identify 'who knows what' in other 
R\&D units. Similar results can be reached through temporary assignments of R\&D personnel to other $R \& D$ facilities. These socialization mechanisms can help achieving inter-unit knowledge transfer and knowledge integration across geographic and disciplinary boundaries, as well as contributing in reducing organizational distance.

\section{RESEARCH METHOD}

The exploratory nature of the questions addressed in this paper makes a case study approach based on data collection the most appropriate research strategy. Data were collected through 24 face-to-face semi-structured interviews with R\&D managers and scientists in six of the largest European pharmaceutical companies (some descriptive statistics of the interviewed companies are reported in Table 1). These pharmaceutical companies provide a particularly interesting context in which to investigate our research questions for three principal reasons. First European MNEs in this industry carry out an increasing proportion of their $R \& D$ activities in the US in order to acquire specialised capabilities in biotechnology (Allansdottir et al. 2002, Reger 2000, Senker 1998, Shan and Song 1997, Sharp 1999). Second, the pharmaceutical industry has moved from being a trial-and-error drug discovery process to becoming a more science-based deductive method of search (Arora and Gambardella 1994) which has led to new divisions of labour and new $R \& D$ organisation both across functions (Chiesa 1996b) and across borders (see Appendix for a description of the drug discovery process and its latest development). Finally, this sector has recently undergone a process of consolidation that has been characterised by complex mergers and acquisitions (M\&A) among large incumbents firms. In this context of organisational distance between R\&D units that previously belonged to competing companies and lack of interpersonal relationships among R\&D personnel, building a 
better understanding of how knowledge diffusion and integration is achieved, is critically important.

$* * * * * * * * * * * * * * * \operatorname{INSERT~TABLE~} 1 * * * * * * * * * * * * * * * * * *$

Between two to six interviews of one and half hours were carried out in each company between June 2002 and April 2003. The interviews were based on two separate but overlapping sets of questions for the managers and the scientists. This allowed corroborating the validity of the data that might otherwise be biased depending on the position of the individuals within the organisation. The interviews were transcribed and the data analyzed for commonalties based on the research question. Some excerpts of the interviews are reported in the empirical section of the paper.

\section{THE R\&D ORGANIZATIONAL STRUCTURE}

Before discussing in more details the managerial challenges faced by these companies and their adopted strategies to overcome them, in this section we analyse their R\&D organizational structure and its evolution over time.

As can be seen from Table 2, all the companies in the sample have an $R \& D$ presence in several continents with foreign research facilities actively engaged in drug discovery activities in one or more therapeutic areas. The therapeutic alignment of each location is determined by the pre-existing capabilities of the research units, especially for those companies that have recently merged (e.g. GSK, Aventis and AstraZeneca) and by the host-country specialization. ${ }^{1}$

$* * * * * * * * * * * * * *$ INSERT TABLE $2 * * * * * * * * * * * * *$

\footnotetext{
${ }^{1}$ Note that across all companies drug discovery in oncology and immunology is mainly concentrated in the US facilities. This is in line with the US specialization in bio/gene technologies.
} 
From an organizational point of view we found two important results. First, across all companies drug discovery activities are organized differently from the drug development phases. The innovative efforts in the drug discovery phase are carried out in an integrated network of research facilities, while the organisational structure of the development activities is organised as a polycentric decentralised structure characterised by a lower level of inter-unit interaction. Second, we identified two different integrated network structures in the drug discovery phase: one represented in Figure 3, which more closely reflects the ideal integrated network organization (see Figure 2) and which does not represent a radical change from the pre-existing organizational configuration (see Figure 7), and another, shown in Figure 5, adopted by Glaxo Smith Kline and Aventis, which represents a more innovative response to the challenges and costs of the integrated network structure.

$* * * * * * * * * * * *$ INSERT FIGURE 3

In Novartis, Roche, Schering and AstraZeneca all the activities connecting to the identification and optimization of the compound are carried out in geographically dispersed research units specialized on specific therapeutic areas (with a minimum of three for the case of Schering to a maximum of eight for AstraZeneca). In each centre a critical mass of scientists and technicians specialised in a set of targets for a disease area are brought together, facilitating personal interaction and the exchange of tacit knowledge. The organisation of research activities according to therapeutic areas has been made possible by the new heuristic in drug discovery (see Appendix). This more systematic method has allowed scientists to focus on specific groups of targets in particular centres of expertise. This allows the firm to access multiple external knowledge sources from centres of excellence around the world and/or internal knowledge sources from research units with a strong technological background within 
the organisation. At the same time the firm's innovative efforts are enhanced by greater interaction among researchers, which is necessary for succeeding in tasks that rely heavily on tacit abilities and trial-and-error activities. The following comments illustrate this point:

'It is important and easy to have pharmacology and chemistry in the same location, because the work of these two departments is very much interconnected'.

'We prefer to have a project in one site within the domain of the project from synthesis, to analytics and screening. All these functions are more easily and efficiently done in one site'.

This network structure is characterised not only by very intense intra-unit but also inter-units knowledge flows especially when there is more than one research centre specialised in the same therapeutic area.

Development activities, instead, tend to be concentrated in a few locations in order to achieve critical mass and economies of scale. As explained by an R\&D manager:

"The studies associated with the discovery of a compound are quite small. They can be located in one place, but studies associated with the development of a compound are big and you need a large organization to cope with these studies”

Similarly a scientist commented:

"In development, economies of scale is the biggest benefit. But in research, size does not seem to help. You want small group agile not tied up with bureaucracy, thinking innovatively, making use of the cultural differences. In research smaller is better”

These development units are mainly located in the home country and the US with the aim of being near the largest markets and the regulatory authorities. They usually confine themselves to developing the results from research units located in the same region and are coordinated by a global development centre. The degree of interaction among the development centres is not as intense as among the research network although they frequently carry out studies for other development centres whenever these have problems of insufficient capacity. 
Roche has organized its R\&D activity in four research sites, two in the US (Palo Alto, California, and Nutley, New Jersey), one in Switzerland and one in Germany, where all the drug discovery functions are carried out up to the pre-clinical development phase. Pre-clinical and clinical studies are instead concentrated only in two centres, one in Europe and one in the US, to support the submission of drug to the local health authorities (see Figure 4). Similarly in Novartis, established by a merger between Sandoz and Ciba-Geigy in 1997, all the phases of the drug discovery process up to the pre-clinical stage are performed in each of the research sites. The compound is further developed in Basel, the US and the UK. Likewise in Schering since 2001 there have been five Research Business Areas (in vivo diagnostic, Neurology/Immunology/Cardiovascular, Dermatology, Gender Health Care and Oncology) which are attached to three research sites (Berlin, Richmond, US, and Mubara, Japan). The activity of each research site is supported by three regional research centres in Europe, Japan and the US. In AstraZeneca, the company resulting from a merger between Astra and Zeneca in 1999, each site is a fully-fledged R\&D facility engaged in activities which range from early discovery to life-cycle management in a particular therapeutic area.

If this organizational structure allows these companies to access knowledge from the US universities and to make contacts with US biotech firms (as outlined by an R\&D manager), managing and coordinating the network of integrated laboratories is extremely costly because you have to move key project members from one site to another. In order to reduce these costs, GSK and Aventis have concentrated certain phases of the drug discovery process in centres of excellence and have implemented a different network structure shown in Figure 5. 
As a result, inside the integrated network structure there are small, autonomous, and flexible units able to take decisions more rapidly and freely as regards the allocation of resources and the establishment of collaborations with external partners. At the same time they are 'almost set up like independent operations if they were small biotechnology companies' (as an R\&D manager explained) and they compete for the resources that are distributed according to how close their molecules are to the market and how well they have performed. However, as we will discuss in the next section, this structure can lead to inefficiency in terms of lack of inter-unit communication and knowledge fertilization.

Since the merger of Glaxo Wellcome and Smith Kline Beecham in 2000, the early phase of their discovery process has become a global function located primarily in the UK, in the US and in Italy (see Figures 6). Once molecules have been identified and optimised they are passed over to the Centres of Excellence of Drug Discovery (CEDDs) which are aligned by therapeutic areas; and chemists and biologists, experts in the disease in question, can work closely to bring the compound to the proof of concept phase. Once the compound has reached this stage, it is transferred to global development functions where it undergoes further clinical tests.

$* * * * * * * * * * * * * * * *$ INSERT FIGURE 6

Similarly, in Aventis there are three drug-discovery sites (Paris, Frankfurt and Bridgewater, US) that are set up as entrepreneurial units and compete on a global basis for resources. Each site has responsibilities from the early phase of a project up to the proof of concept phase, but the project team gets support from the so-called Global Functions of Lead Generation and Lead Optimisation. There is a Global Drug 
Development centre in Bridgewater, from where all clinical development activities subsequent to the proof of concept stage are coordinated. Clinical trials are carried out all over the world, monitored by regional development centres in Paris for Europe, in Tokyo for Japan, in Bridgewater for the US. This R\&D organisation has been in place since the creation of Aventis, which resulted from the merger of Hoechst and RhonePoulenc in 2000.

The existing R\&D network organizations have evolved from a hub-structure where each centre had the responsibility to pursue research in certain therapeutic areas under the coordination of the headquarters (see Figure 7). Each centre was organised as a completely self-sufficient $R \& D$ unit, where most of the phases of the drug discovery and development process were carried out. Each R\&D centre was fairly independent and there was an element of competition among the different units. In general communication among the different sites was not very intense and cross-border team projects were not often implemented, as shown by the following comments of both scientists and R\&D managers:

'Things were worked almost exclusively in each site. Each location was self-contained, they had all the resources to carry out all the function that a project required. There were no cross-national teams.'

'The research sites were much more independent of each other. They had their own budget and the head of each site was responsible for everything. There was a certain level of competition between different sites, we did not work very effectively together as a group'.

'Now people here talk to people there which was not the case before, because they were in competition with each other. The competition emerged when we had to decide who had to work on a specific target. Now we have common projects which do not contribute to a specific research centre's productivity but they contribute to the whole organization'

As can be seen by comparing Figure 3 and 7, the integrated network structure implemented by Novartis, Roche, AstraZeneca and Schering represents a 'natural' evolution from the previous hub-structure although in the old configuration there was 
not geographical and organizational separation between the research and development functions. GSK and Aventis's organizational structure entails a more radical change from the pre-existing structure, which however reflects a trend towards recentralisation and consolidation in few and small leading research centres to reduce costs, increase flexibility and productivity through inter-unit competition (a trend identified also by Gassmann and von Zedtwitz 1999).

Although there is a movement away from a centralised and co-located organizational structure towards an internationally distributed network there is same evidence of organizational inertia. In other words, although the motto of one of these companies is 'think global act global' and there is a managerial effort in using resources globally, scientists appear to build their innovative efforts using pre-existing routines which have been developed in the pre-existing organizational structure. This is also reflected in the way they exploit their personal network of relationship inside the company. As noted by a senior researcher:

'Although we have an electronic archive with lists of expertise and contacts, I rely on my personal contacts. You can store as much information as you want, but it only becomes knowledge if you know the other person'.

\section{EVIDENCE OF GEOGRAPHICAL, TECHNOLOGICAL, ORGANIZATIONAL DISTANCE AND INTER-UNIT RIVALRY}

The existing organisation of research activities is thus quite complex and involves a high degree of lateral communication among geographically dispersed research centres that operate in an integrated way during the drug discovery process. The complexity of the knowledge diffusion process inside the network derives from the fact that knowledge acquired in a particular therapeutic area has to be transmitted not only to other units working in the same therapeutic area but also to other therapeutic areas where it could be employed. Results from the drug discovery process must also 
be transferred to the units carrying out development activities. One of the potential problems inherent in this structure is thus the lack of integration of knowledge produced in geographically distant units which could result in a decrease in the firm's innovation performance and lack of cross-fertilisation of knowledge across different therapeutic areas.

As illustrated in the previous section research and development units are scattered around the world thus geographical distance is a common characteristic of both types of integrated network organizations. Organizational distance is also a common feature of these firms because, as shown in Table 2, most R\&D centres were created from pre-existing research facilities which used to belong to different companies and because drug discovery and development activities are organized separately. Finally, there is a high degree of inter-unit technological distance because each centre is specialised in a different therapeutic area or in different approaches to a particular disease.

The increased specialisation of knowledge used in investigating specific therapeutic targets and, within these, particular methodological approaches ${ }^{2}$ is the main cause behind the high level of inter-unit technological distance, as shown also by the comments of a chemist and a toxicologist:

'I communicate very rarely with scientists in other locations because the therapeutic area I am working on is only located here. I do not have formal contacts with other colleagues ... other colleagues working in other therapeutic areas have completely different structures, different chemistry, we can hardly ever help each other'.

'I would use very little the R\&D results from other subsidiaries, because our projects are very separated, they have different target indications as compared to what we are

\footnotetext{
${ }^{2}$ As pointed out by an R\&D manager in the area of oncology: 'Each site focused on oncology is specialised in a particular treatment paradigm: the functional treatment paradigm (i.e. hormones), and the anti-angio-genesis paradigm (i.e. we try to block the nutrition of the cancer cells) are investigated in Europe, while in the US they are more exploring the use of gene therapy and immunology to fight cancer'.
} 
doing, so I would not have very much exchange of data, because we do not overlap' (emphasis added).

In GSK and Aventis' drug discovery organisation inter-unit technological and organizational distances seems to be more severe because of the way the centres of excellence have been created. As a GSK R\&D manager explained:

'The CEDDs are almost like separate companies, they have their own budget, their own ways of working. One of the dangers of the CEDDs is that they might end up not sharing best practices. The CEDDs have various levels of communication, but it is pretty poor, because they have been set up almost like small companies. They are almost in competition, they are evaluated based on the value that the particular CEDD delivers to the business. In addition people do not move between CEDDs because they have expertises in a specific therapeutic area' (emphasis added).

The same view was provided by a senior scientist:

'The CEDDs are more geographically located and among them there is a minimum level of communication, mostly based on personal relationships. Most of the people in Upper Marion do not know the people in North Carolina because they used to belong to different companies.'

The inter-unit rivalry strategically introduced in order to achieve 'biotechnology style mind sets' has created barriers in the internal knowledge diffusion and integration process. Researchers working in distant locations do not communicate not only because they do not know each other or because they are working in very different areas but also because there are in competition with each other (the absence of arrows in Figures 5 and 6 among different centres excellence reflects the lack of communication among these units).

\section{IMPLEMENTED SOLUTIONS: ORGANIZATIONAL AND SOCIAL MECHANISMS}

There are some organizational measures in place to reduce geographical and crossdisciplinary boundaries. Projects to develop a drug are carried out by people working across different functions. These firms organize their research projects according to a certain disease area rather than by a geographical location, which implies that 
people from different research sites might work together in cross-border team projects.

In GSK the main organizational knowledge integrator across CEDDs are the global functions (discovery and genetic research and drug development). As shown in Figure 6, the CEDDs are all in contact with both the research units involved with the identification and optimization of the compound, as well as the development units running the clinical trials. As explained by a senior scientist in drug development:

'Because we are a global function and the CEDDs are six centre of excellence around the world each doing a different thing, if we are not careful they can go in different directions. By working with the global functions it means that if we develop a technology that it is useful to the CEDDs we can make it available to all the CEDDs. Or if we see that in one location a CEDD develops a technology that can be useful to us (or to other CEDDs), we can help channel that technology because we are in contact with all the CEDDs.'

In most companies there are also specific task force of experts in particular target family, such as kinesis or proteases, or inflammatory targets with applicability to all disease areas (called platforms in Aventis). These experts support the projects teams located in different research units by collecting all the information in-house about these targets and also by following the development in these areas outside the firm. The task of this group of experts is to integrate and diffuse the knowledge across different locations and therapeutic areas.

An organizational measure adopted by one company is cross-disciplinary project proposal review boards. These boards are formed by peer reviewers coming from different areas and from different R\&D units that can facilitate the cross-fertilization of knowledge across therapeutic areas and locations.

However to avoid compartmentalisation along disciplines firms also try to increase the level of communication among scientists working on different therapeutic areas and in distant locations using socialization mechanisms. Cross-border and cross- 
disciplinary projects are frequently employed. Due to the organisational setting of the R\&D function it is often the case that researchers from different locations are involved at different stages in a drug discovery project. However cross-border team projects are seen more as an unavoidable consequence of the $R \& D$ organisation than as a strategic means for increasing knowledge diffusion inside a geographically dispersed R\&D network. This clearly emerges from the comments of R\&D managers:

'The one-location team is the preferable model because it is the more efficient, but the reality of our organisation is that most of our teams have members based in at least two countries and some of them three. My personal view is that if you can have one location team you are going to be better off, if you can have all sitting in one corridor is going to work better. But this is [now] the exception to the rule'.

'I think that the best solution is to have everybody in the same location. But it is good to have diversity, but it is very difficult to communicate especially with Japanese because of language barriers and the cultural differences. This is also a problem in the US'

Temporary assignments appear to be the preferred socialisation mechanism when firms aim to achieve transfers of know-how from the discovery to the development phase. This handover from research to development is 'very tricky' (as defined by an R\&D manager) because there is a departmental change. 'Research tries to ensure that the product survives up to the point it is passed over to the development phase. In development people would not trust what has been in research'. To overcome the inter-unit attrition researchers from the development function work closely with the discovery team for up to a year before the compound has been identified.

\footnotetext{
'What we would often do is to have a period of secondment where a medicinal research chemist [from research] will spend sometimes in process chemistry [in the drug development phase]. And sometimes the process research chemist will follow the compound and spend some time in secondment at the manufacturing site chemistry [in the drug production stage]. We try to optimize the information and the knowledge flow but it is also good because they gain experience and start seeing things in a different way'

'The way we approach the hand-over from research to development is that the people will work very closely with the discovery people up to one year before the compound is finally identified. We use secondments and short-term assignments (from three to six months) we have people who travel a lot in terms of maintaining relationships'
} 
Longer term assignments (from 6 months to one year) are also used, although to a lesser extent. They accomplish three purposes: inter-unit knowledge transfer, identifying 'who knows what' in other locations and reducing inter-unit attrition. Indeed increasing organizational proximity through the creation of personal relationships between researchers working in distant $R \& D$ facilities was the main motivation behind an exchange programme put in place by one of the companies:

'Historically, communication and cooperation between European and US sites has been difficult due to the different research philosophies. During the mid 1990s there was more competition than cooperation with them. During that time it was even difficult to exchange knowledge. To overcome cultural differences and to increase a common understanding among colleagues from different continents, staff exchange programs have been established. Now, after the first exchange of staff, things are improving ... People taking part in the exchange programme should be the bridge between the two sites. It is important to know people, it is much easier to deal with them if you have worked with them' (emphasis added).

Transfers of know-how between research units are more difficult to achieve especially when they are specialised in different therapeutic areas. Companies try to stimulate interdisciplinary knowledge flows by promoting and officially supporting communities of scientists and technology councils. Technology councils are set up to discuss problems faced in using particular technologies, such as those used in combinatorial chemistry or high through-put screening. The members of these communities interact regularly through intranet, meetings and formal workshops. These councils provide a forum where individuals can share best practice and some of the challenges they face in using a particular technology or dealing with critical tasks or topic in a particular discipline.

\section{Conclusions}

MNEs have evolved in a short span of time from simple centralised structures to complex modes of organisation such as the multi-hub structure, in response to the processes of globalization. These structures have allowed the MNE to take advantage 
of dispersed sources of knowledge and to exploit synergies across the different R\&D centres through cross-border innovation projects. Furthermore, different structures are used for research activities than for development activities, reflecting the different character of the two aspects of innovation.

However, as this paper highlights, implementing changes in organisational structures - particularly for R\&D activities - to more efficiently exploit resources and capabilities on a global basis poses a variety of managerial challenges. Some of these challenges are more general, in the sense that they apply to all aspects of value adding activities within a globally integrated MNE, such as the complexities of promoting and integrating knowledge flows in the face of inter-unit geographical, organizational and technological distance. As innovation activities are primarily about the creation and diffusion of knowledge, much of which is tacit and non-codifiable, a higher degree of lateral communication among dispersed research centres is required. This is achieved through a variety of organizational and socialization mechanisms, some of which we have discussed here.

In addition though, inter-unit, inter-disciplinary and intra-disciplinary rivalries - some of which have been purposely created to promote innovativeness through competition- act also as a barrier to achieving greater cross-fertilization and the integration of knowledge. Some of these derive from the nature of research activities, and the difficulties inherent in promoting greater interaction between scientists engaged in focused research within highly specialised disciplines. However, others derive from the absence of central coordinating mechanism that a 'traditional' headquarters operation may have provided in a centralised hub scenario, which might perform the function of an 'honest broker'. 
Thus, while multi-hub structures have undoubted benefits, they have also generated new costs, particularly in terms of creating unbiased and transparent means to promote lateral communications both between centres of excellence as well as geographically dispersed units. To be certain, some of this simply represents organizational inertia - formal and informal institutions that define the nature and direction of interaction within a new structure take considerable time to be refined to achieve optimal efficiencies. Nonetheless, the evidence presented here points to the continued- if not greater- investment in human, managerial and financial resources to promote knowledge integration within a geographically and technologically dispersed R\&D structure. 


\section{REFERENCES}

Agrawal, A., I. Cockburn and J. McHale, 2003. Gone but not forgotten: labour flows, knowledge spillovers, and enduring social capital, NBER Working Paper No. 9950.

Allansdottir, A., A. Bonaccorsi, A. Gambardella, M. Mariani, L. Orsenigo, F. Pammolli and M. Riccaboni, 2002. Innovation and competitiveness in European biotechnology, Enterprise papers No. 7.

Allen, T. J., 1970. Communication networks in R\&D laboratories. R\&D Management 1 (1), 14-21.

Allen, T. J., 1977. Managing the Flow of Technology ${ }_{2}$ Cambridge, MA, MIT Press.

Arora, A. and A. Gambardella, 1994. The changing technology of technological change: general and abstract knowledge and the division of innovative labour. Research Policy 23 (5), 523-532.

Bartlett, C. A. and S. Ghoshal, 1990. Managing innovation in the transnational corporation, in: Managing the Global Firm. C. Bartlett, Y. Doz and G. Hedlund (Eds.) London, Routledge.

Chiesa, V., 1996a. Managing the internationalisation of R\&D activities. IEEE Transactions on Engineering Management 43 (1), 7-23.

Chiesa, V., 1996b. Separating research from development: evidence from the pharmaceutical industry. European Management Journal 14 (6), 638-647.

Chiesa, V. and R. Manzini, 1996. Managing the transfer of knowledge within multinational firms. International Journal of Technology Management 12 (4), 462-476.

Cohen, W. M. and D. A. Levinthal, 1990. Absorptive capacity: a new perspective on learning and innovation. Administrative Science Quarterly 35 (1), 128-152.

Cyert, R., 1995. Management of knowledge, Newsletter of the Carnegie Bosch Institute for Applied Studies in Management.

De Meyer, A., 1993. Internationalising R\&D improves a firm technical learning. Research Technology Management 36 (4), 42-49.

Gassmann, O. and M. von Zedtwitz, 1999. New concepts and trends in international R\&D organization. Research Policy 28 (2-3), 231-250.

Grant, R., 1996. Toward a knowledge-based theory of the firm. Strategic Management Journal 17 (Winter Special issue), 109-122.

Gupta, A. K. and V. Govindarajan, 2000. Knowledge flows within multinational corporations. Strategic Management Journal 21 (4), 473-496.

Håkanson, L. and R. Nobel, 2000. Technology characteristics and reverse technology transfer. Management International Review 40 (Special issue), 29-48.

Håkanson, L. and R. Nobel, 2001. Organization characteristics and reverse technology transfer. Management International Review 41 (Special issue), 392-420.

Hannan, M. T. and J. Freeman, 1984. Structural inertia and organizational change. American Sociological Review 49 149-164.

Hannan, M. T., P. Laszlo and G. R. Carroll, 2002. Structural inertia and organizational change revisited III: the evolution of organizational inertia, Research Papers Series No. 1734.

Hansen, M., 1999. The search-transfer problem: the role of weak ties in sharing knowledge across organization subunits. Administrative Science Quarterly 44 82-111. 
Hedlund, G., 1986. The hypermodern MNC - A heterarchy? Human Resource Management 25 9-35.

Henderson, R. and I. Cockburn, 1994. Measuring competence? Exploring firm effects in pharmaceutical research. Strategic Management Journal 15 (Winter Special Issue), 63-84.

Holm, U. and T. Pedersen, 2000. The emergence and impact of MNC centres of excellence. A subsidiary perspective, London, MacMillan Press.

Howells, J., 1995. Going global: the use of ICT networks in research and developments. Research Policy 24 169-184.

Kogut, B. and U. Zander, 1992. Knowledge of the firm, combinative capabilities, and the replication of technology. Organization Science 3 (3), 383-397.

Kogut, B. and U. Zander, 1993. Knowledge of the firm and the evolutionary theory of the multinational corporation. Journal of International Business Studies Fourth Quarter 625-645.

Nightingale, P., 2000. Economies of scale in experimentation: knowledge and technology in pharmaceutical R\&D. Industrial and Corporate Change 9 (2), 315-359.

Persaud, A., U. Kumar and V. Kumar, 2001. Harnessing scientific and technological knowledge for the rapid deployment of global innovations. Engineering Management Journal 13 (1), 12-18.

Reger, G., 2000. Internationalization of research and development in pharmaceuticals, in: Changing Innovation in the Pharmaceutical Industry. A. Jungmittag, G. Reger and T. Reiss (Eds.) Berlin, Springer-Verlag.

Reger, G., 2004. Coordinating globally dispersed research centres of excellence-the case of Philips Electronics. Journal of International Management 10 51-76.

Reiss, T. and S. Hinze, 2000. Innovation process and techno-scientific dynamics, in: Changing Innovation in the Pharmaceutical Industry. A. Jungmittag, G. Reger and T. Reiss (Eds.) Berlin, Springer.

Senker, J., 1998. Biotechnology and Competitive Advantage, Cheltenham, Edward Elgar.

Shan, W. and J. Song, 1997. Foreign direct investment and the sourcing of technology advantage: an evidence from the biotechnology industry. Journal of International Business Studies 28 (2), 267-284.

Sharp, M., 1999. The science of nations: European multinationals and American biotechnology. International Journal of Biotechnology 1 (1), 132-159.

Szulanski, G., 1996. Exploring internal stickiness: impediments to the transfer of best practice within the firm. Strategic Management Journal 17 (Winter Special Issue), 27-43.

Teigland, R., C. Fey and J. Birkinshaw, 2000. Knowledge dissemination in global R\&D operations: an empirical study of multinationals in the high technology electronics industry. Management International Review 40 (1), 49-78.

Tsai, W. and S. Ghoshal, 1998. Social capital and value creation: the role of intra-firm networks. Academy of Management Journal 41 474-476.

von Zedtwitz, M. and O. Gassmann, 2002. Market versus technology driven in R\&D internationalisation: four different patterns of managing research and development. Research Policy 31 (4), 569-588.

Westney, D. E., 1993. Cross-Pacific internationalization of R\&D by U.S. and Japanese firms. R\&D Management 23 (2), 171-181.

Zander, I., 1999. How do you mean 'global'? An empirical investigation of innovation networks in the multinational corporation. Research Policy 28 (2-3), 195-213. 
Zhou, C. and T. Frost (2003). Centrifugal forces, R\&D co-practice, and reverse knowledge flows in multinational firms. Paper presented at the annual AIB conference 'The Power of Ideas and International Business', July 5-8, Monterey, CA. 


\section{APPENDIX}

\section{RESEARCH AND DEVELOPMENT IN THE PHARMACEUTICAL INDUSTRY}

The drug discovery and the development process can be divided in six stages (see figure A1). The first three stages comprise the drug discovery phase, which aims to identify new compounds; and the remainder of the process comprises the development phase, when compounds are tested to assess their efficacy and tolerability. The division between research and development is not clear-cut and certain companies classify under research part of the clinical development up to the proof of concept.

Figure A1. The drug discovery process

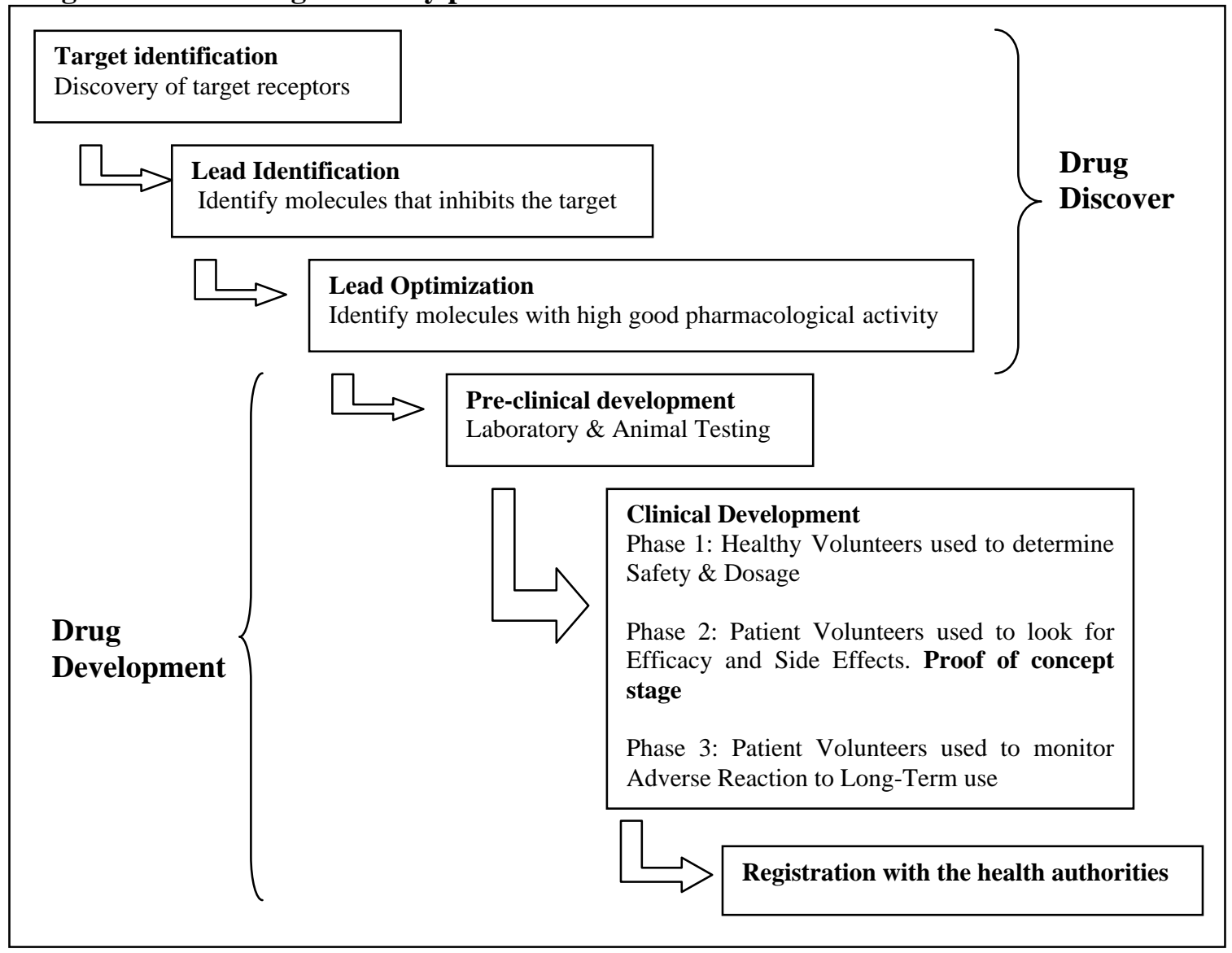

Developments in the technologies employed in the drug discovery phase have completely changed the nature of the research process in the pharmaceutical industry (Arora and Gambardella 1994, Henderson and Cockburn 1994, Nightingale 2000, 
Reiss and Hinze 2000). Traditionally the discovery of a new compound was the result of a trial-and-error process during which thousands of compounds were screened in order to find one with a specific biological profile, because in general the 'mechanism of action' of a compound was not clearly understood. This process required huge laboratories to conduct large-scale screening, and extensive financial, human and technological resources. During the 1990s the introduction of what are known as enabling technologies, such as high through-put screening, combinatorial chemistry, bio-informatics, and scientific advances in biomedical sciences have completely transformed the experimental design and the drug discovery process. The discovery of a drug is now the result of a science-deductive method and researchers know which biochemical and molecular pathways they want to block or stimulate.

As argued by Chiesa (1996b) the use of new technologies has reduced both the time needed to test potential active substances, and the number of researchers required. As a result there have been important changes in the organisation and management of the $R \& D$ function. In essence the size of the experimental unit has been reduced and the degree of knowledge specialisation has increased, as has as the number of relevant scientific disciplines. In addition the new technological paradigm in drug discovery has reduced the importance of tacit and context-specific knowledge in certain phases of this process. However the development of a drug still requires large amounts of human and financial resources and its efficiency relies on the achievement of a critical mass to carry out highly standardised large-scale activities. 
Figure 1 The centralised hub R\&D structure

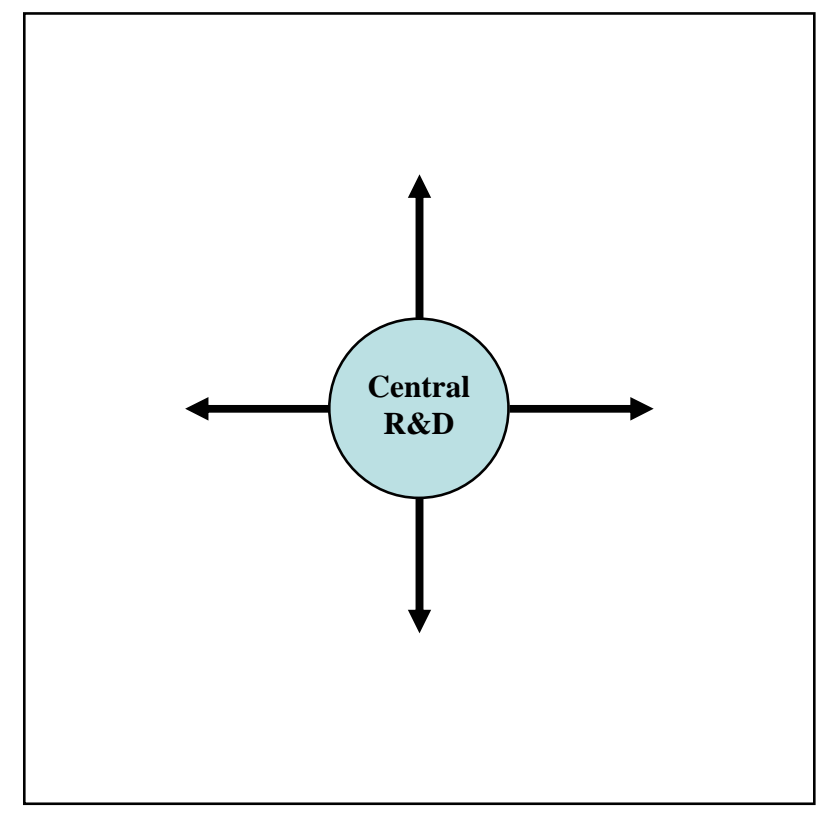

Figure 2 The integrated R\&D network structure

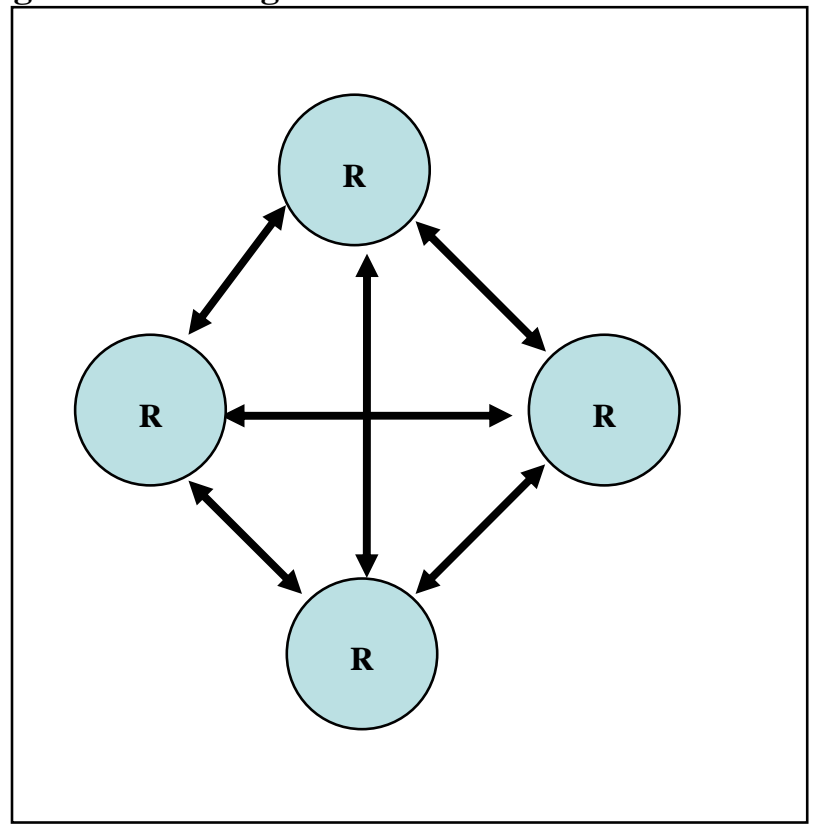


Figure 3 The integrated network structure in drug-discovery and development

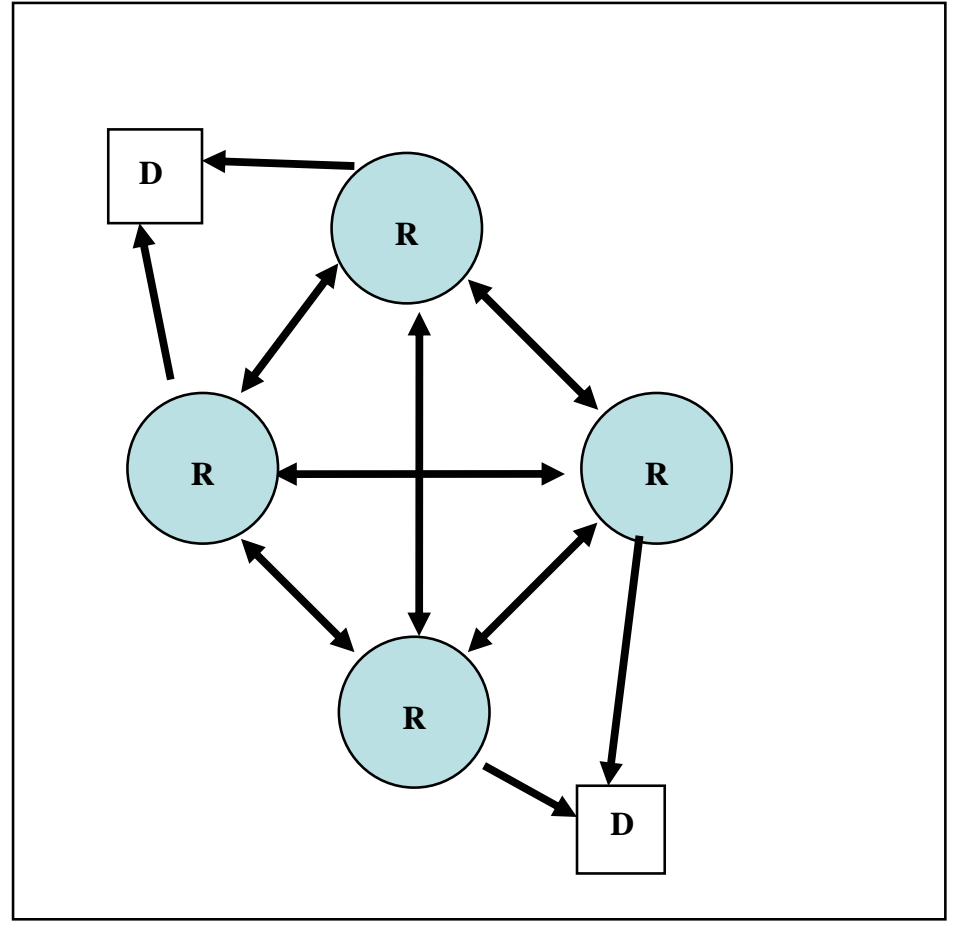

Figure 4 Roche's R\&D organization

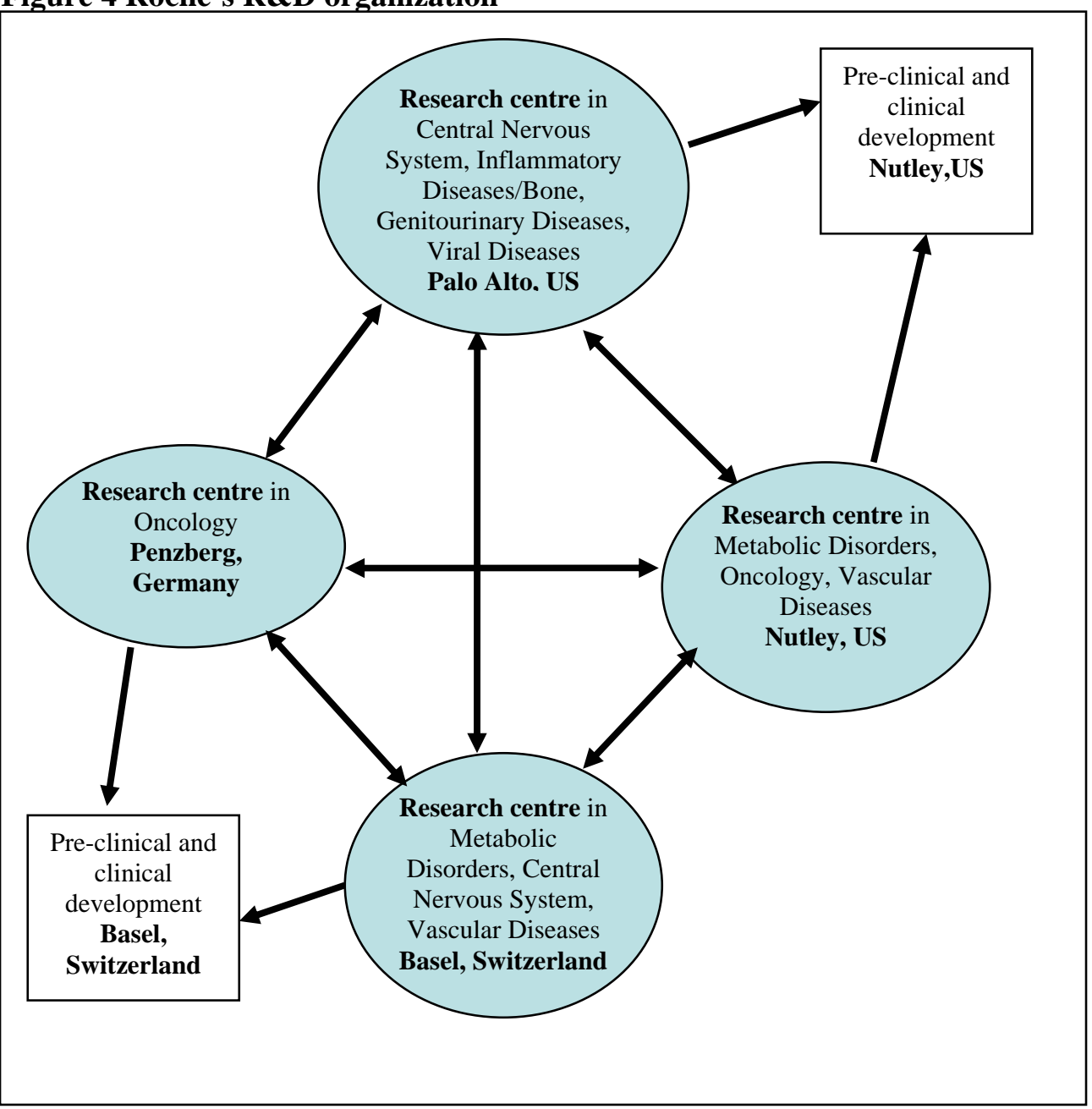


Figure 5 Integrated network structure with centres of excellence for drug discovery

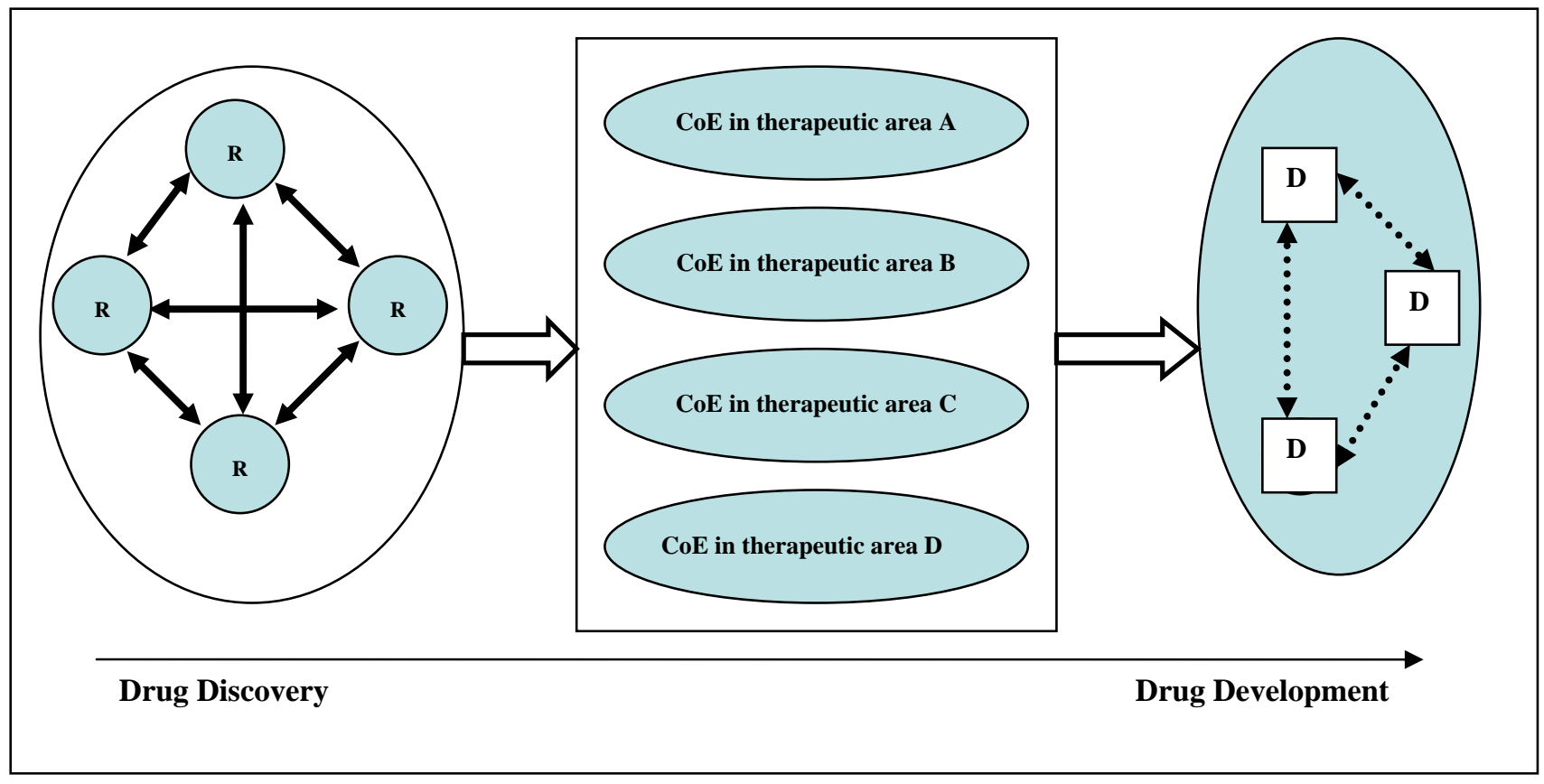

Figure 6 Glaxo Smith Kline R\&D organizational structure

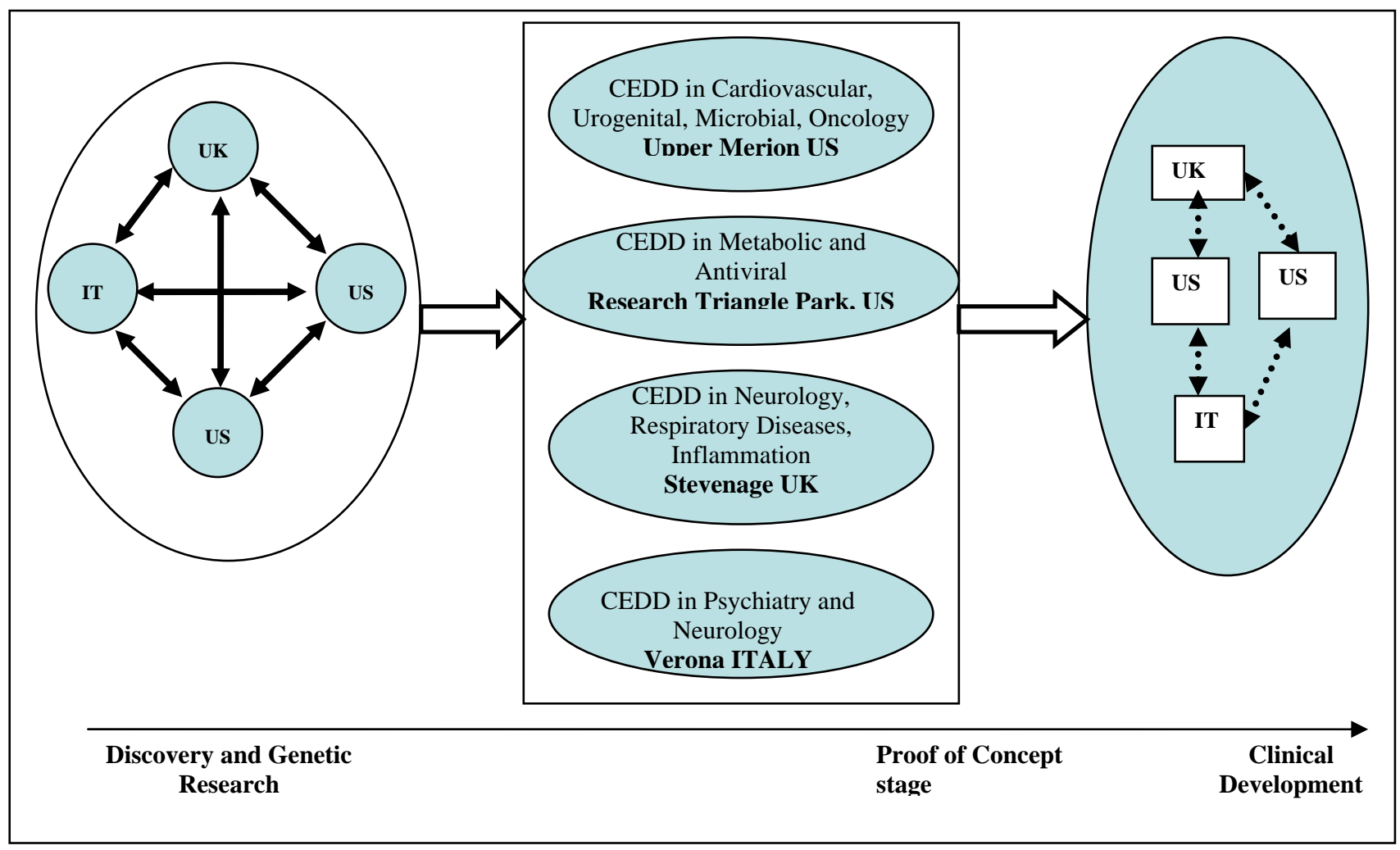


Figure 7 The R\&D hub-structure

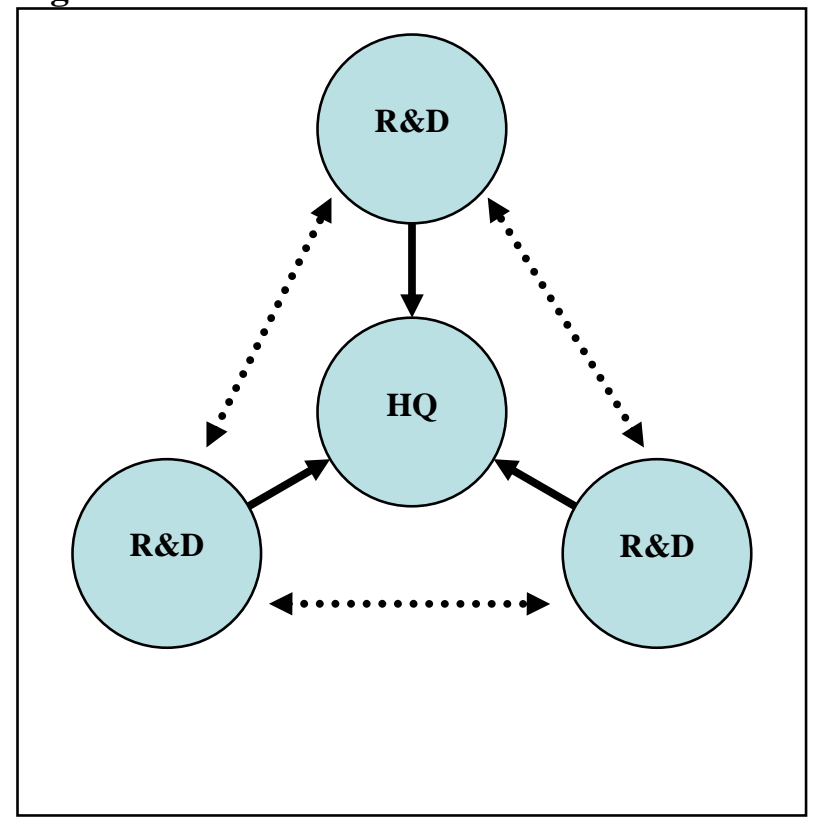


Table 1 Description of the interviewed companies

\begin{tabular}{|c|c|c|c|c|c|c|c|}
\hline Company name & $\begin{array}{c}\text { Corporate } \\
\text { headquarters }\end{array}$ & $\begin{array}{c}2002 \text { Pharmaceutical } \\
\text { revenues in \$ }\end{array}$ & Rank & $\begin{array}{l}\text { No. of Employees } \\
\text { in } R \& D^{1} \\
\end{array}$ & $\begin{array}{c}2002 \text { R\&D } \\
\text { expenditure in } \$^{1}\end{array}$ & Rank & $\begin{array}{c}\text { No. of interviews } \\
\text { conducted }\end{array}$ \\
\hline AstraZeneca & London & 17,841 & 4 & 11,000 & 3,069 & 4 & 5 \\
\hline Aventis & Strasburg & 16,639 & 6 & 5,600 & 3,235 & 5 & 4 \\
\hline GlaxoSmithKline & London & 27,060 & 2 & 15,000 & 4,108 & 2 & 5 \\
\hline Novartis & Basel & 13,547 & 8 & 3,000 & 2,799 & 6 & 2 \\
\hline Roche & Basel & 9,355 & 13 & 5,030 & 2,746 & 7 & 3 \\
\hline Schering & Berlin & 3,074 & 19 & 1,200 & 869 & 19 & 5 \\
\hline
\end{tabular}

Source: Revenues, R\&D expenditures and ranking data are from the Contract Pharma Ranking of top 20 pharmaceutical companies (www.contractpharma.com).

${ }^{1}$ Not all R\&D employees and expenditure are in the pharmaceutical business of these companies. 
Table 2 Geographical distribution of research centres and their specialisation

\begin{tabular}{|c|c|c|c|}
\hline Company & Previously part of & Company & Therapeutic Areas \\
\hline & Astra & Mölndal, Sweden & Neurology, Respiratory Diseases, Inflammation \\
\hline Astra & Astra & Gothenburg, Sweden & Cardiovascular, Gastrointestinal \\
\hline & Astra & Lund, Sweden & Respiratory \\
\hline & Zeneca & Wilmington, Delaware, US & Central Nervous System \\
\hline & New & Boston, US & Oncology, Infection \\
\hline Aventis & Hoechst & Frankfurt, Germany & Cardiovascular Diseases, Metabolic Diseases, Osteo-arthritis \\
\hline \multirow{4}{*}{ GSK } & Smith Kline Beecham & Upper Merion, Philadelphia, US & Cardiovascular, Urogenital, Microbial, Oncology \\
\hline & Glaxo Welcome & Research Triangle Park, North Carolina, & Metabolic and Antiviral \\
\hline & Glaxo Welcome & Stevenage, UK & Neurology, Respiratory Diseases, Inflammation \\
\hline & Glaxo Welcome & Verona, Italy & Psychiatry, Neurology \\
\hline \multirow{2}{*}{ Novartis } & Sandoz & Tsukuba, Japan & Oncology, Arthritis \\
\hline & New & Cambridge Massachusetts, US & Cardiovascular diseases, Metabolism, Infectious diseases. \\
\hline \multirow{4}{*}{ Roche $^{1}$} & Acquired in 1994 & Palo Alto, California, US & $\begin{array}{l}\text { Central Nervous System, Inflammatory Diseases/Bone, Genitourinary } \\
\text { Diseases, Viral Diseases }\end{array}$ \\
\hline & & Nutley, New Jersey, US & Metabolic Disorders, Oncology, Vascular Diseases \\
\hline & & Basel, Switzerland & Metabolic Disorders, Central Nervous System, Vascular Diseases \\
\hline & & Penzberg, Germany & Oncology \\
\hline \multirow{3}{*}{ Schering } & & Richmond, California, US & Neurology, Immunology, Cardiovascular, Oncology \\
\hline & & Berlin, Germany & In Vivo Diagnostic, Radio Pharmaceuticals, Neurology, Immunology, \\
\hline & Acquired in 2000 & Mobara, Japan & Oncology, Neurology \\
\hline
\end{tabular}

